\title{
ТЕАТРАЛЬНЕ ЖИТТЯ ЛЬВІВСЬКОЇ ГРЕКО-КАТОЛИЦЬКОЇ ДУХОВНОЇ СЕМІНАРІЇ КІНЦЯ ХУІІІЕРШОЇ ПОЛОВИНИ ХІХ СТ.
}

vyshchoi osvity [Recommendations for the introduction of blended learning in vocational institutions before higher and higher education]. Ministry of Education and Science of Ukraine. Available at: https://mon.gov.ua/storage/app/ media/vishcha-osvita/2020/zmyshene \%20navchanny/ zmishanenavchannia-bookletspreads-2.pdf[in Ukrainian].

6. Khmil, O.V., Kaskova, L.F., Khmil, D.O., Kolot, E.H. Berezhna, O.E. \& Soloshenko, Yu.I. (2017). Metody orhanizatsii samostiinoi roboty v suchasnomu navchanni studentiv [Methods of organizing independent work in modern student learning]. Inovatsiini tekhnolohii v orhanizatsii samostiinoi roboty studentiv medychnykh osvitnikh zakladiv: materialy navch.-nauk. konf. z mizhnar. uchastiu. m. Poltava, 23 bereznia 2017 r. Innovative technologies in the organization of independent work of students of medical educational institutions: Proceedings of the Educational Sciences. Conf. with international participation. Poltava, March 23, 2017. (pp. 176-177). Poltava. [in Ukrainian].

7. Tsiura, S. \& Terzalova, A. Normatyvne zakriplennia poniat "osvitnie seredovyshche", "osvitnii prostir", "osvitnii protses" u konteksti pedahohichnoi terminolohii [Normative consolidation of the concepts "educational environment", "educational space", "educational process" in the context of pedagogical terminology]. Youth and the market: a monthly scientific and pedagogical journal. No.5 / 184. 2020.pp. 111-118. Available at: http://mir.dspu.edu.ua/ index.php/2308-4634/issue/view/13562 [in Ukrainian].

8. Shymko, I. (2005). Problemy orhanizatsii samostiinoi roboty u vyshchii shkoli [Problems of organizing independent work in high school]. Native school. No. 8. pp. 34-35.[in Ukrainian].

Стаття надійшла до редакції 04.01.2021

УДК [792.054:[378.6:271.4]](477.83-25)“1794/1848”

DOI:

Мирослава Циганик, кандидат філологічних наук, доиент кафедри театрознавства та акторської майстерності Львівського національного університету імені Івана Франка

\section{ТЕАТРАЛЬНЕ ЖИТТЯ ЛЬВІВСЬКОЇ ГРЕКО-КАТОЛИЦЬКОЇ ДУХОВНОЇ СЕМІНАРІЇ КІНЦЯ ХVІІІ ПЕРШОЇ ПОЛОВИНИ ХІХ СТ.}

У статті проаналізовано театральну діяльність у стінах Львівської духовної семінарії грекокатоличького обряду в 1794-1848 рр., зазначено тогочасні суспільно-політичні умови, в яких перебувала освіта греко-католищької семінарії у Львові кіния XVIII першої половини ХIX ст. Вказано на основні принципи естетичного виховання семінаристів засобами сиенічного мистеитва. Названо видатні постаті, які під час навчання в семінарії розвинули свої мистецькі здібності та відіграли важливу роль у розвитку украйнського професійного театру в Галичині.

Ключові слова: Греко-католицька духовна семінарія; семінаристи; сценічне мистецтво; українське культурне відродження; театр; “Маркіянове сузір'я”; Рудольф Мох; драма.

Jim. 16.

Myroslava Tsyhanyk, Ph.D.(Philology), Associate Professor of the Theater Studies and Acting Department, Ivan Franko National University of Lviv

\section{THEATRE LIFE OF THE GREEK-CATHOLIC SEMINARY IN LVIV IN THE LATE XVIII CENTURY - THE FIRST HALF OF THE XIX CENTURY}

The article analyzes the theatrical activity of Greek Catholic Theological Seminary in Lviv in 1794-1848, points out the basic principles of teaching the performing arts of seminarians, indicates the then socio-political conditions in which the formation of the Greek Catholic Theological Seminary in Lviv late XVIII first half of the XIX century. The prominent figures that developed their artistic abilities during their studies at the seminary and played an important role in the development of the Ukrainian professional theater in Galicia are named.

Since its establishment in 1873 and till the start of the democratic revolution in the Austrian Empire in 1848, the Greek-Catholic Seminary in Lviv appeared to be at the core of shaping and developing of the artistic tendencies among the nationally conscious Ukrainian youth. Additionally, it happened to be an epicenter of the National Revival, a home for the "Ruthenian Triad" and, in the course of time, the alma mater of the Ukrainian dramaturgy. The dramatic arts'inception found its beginning in 1874 when F. Bogomolets 'play in Polish was put on a performance. Under the guidance of A. Angelovich, the seminarists have been working on learning Ukrainian language, exploring songs and rites. Meanwhile, until 1797, they have been leading a dynamic theatrical life in the Seminary, the key manifestation of which may be found in various scenes staged throughout the holy tides. After the lull, which lasted for more than three decades, the Greek Catholic Theological Seminary in Lviv revived its performances in 1829. Despite the difficult livelihood and the fact, that the cholera epidemic has arisen in Galicia exactly at a time, even 


\section{ТЕАТРАЛЬНЕ ЖИТТЯЛЬВІВСЬКОЇ ГРЕКО-КАТОЛИЦЬКОЇ ДУХОВНОЇ СЕМІНАРІЇ КІНЦЯ ХИІІПЕРШӦ̈ ПОЛОВИНИ ХІХ СТ.}

despite the strict disciplinary procedures imposed by the leadership, i. a. the rector S. Telikhovskiy, the seminarians continued reciting the improvised dialogues clandestinely, while recording and examining folk, translating and writing plays. Being in the middle of the European history along with the uprising of 1848 , christened as the "Spring of Nations", for the first time the Seminary's students have performed a play in Ukrainian language, namely - Ruthenian Wedding by J. Lozynskiy. That same year in Kolomyia I. Ozarkevych performed his "Girl To Be Married, or Endearment Cannot Be Forced", originally based on I. Kotlyarevskiy's play "Natalka Poltavka". Alas, there were sixteen more difficult years prior to establishment of the first Ukrainian professional theater in Galicia. Yet, the nationally oriented effort by rectors A. Angelovich and G. Yakhimovich contributed to raising a few generations involved in the emergence, as well as further promotion of the Ukrainian theater in Galicia.

Keywords: Greek Catholic Theological Seminary in Lviv; seminarists; performing arts; the cultural renaissance in Ukraine; theatre; "Markiyan's constellation"; Rudolf Mokh; drama.

П остановка проблеми. Духовні семінарії, які виникли на українських землях наприкінці XVIII - на початку XIX ст., у своїх навчальних планах охоплювали не тільки душпастирську, а й культурнопросвітницьку, мистецьку та наукову сфери. В освітньому процесі значиму роль приділялося дисциплінам "Пеотика" i "Риторика", які не лише формували універсальну грамотність особистості, а й засобами педагогічних впливів сприяли естетичному вихованню, що тим самим спричинило до розвитку сценічного мистецтва в Україні.

До Львівської греко-католицької духовної семінарії вступали, як правило, діти малозабезпечених верств населення, які не мали можливості навчатися у латинських школах, але виховувалися українським словом, піснею, обрядом. Тому саме питомці семінарії розпочали процес перетворення української народності на найвищу форму етносу - націю. Фольклорна хвиля, яка для покоління початку XIX ст. стала запорукою національного відродження, увібрала в себе й театральний напрям - популярним стало виконувати народні пісні, з'явилися перші постави народного обрядодійства.

Саме галицьке духівництво як зазначив I. Франко у своій праці “"Русько-український театр (історичні обриси)" виступило “плекателями руської літератури, науки, ба також музики і театру" $[15,320]$. Думку авторитетного українського дослідника розділив польський історик театру С. Пепловський, вказавши, що українська сцена бере свій початок від вихованців Греко-католицької семінарії, яка функціонувала у Львові 31783 р. у приміщені монастиря домініканок. Перші театральні вистави у стінах семінарії, як зазначив I. Франко, поставлено в 1794 p. $[8,33]$ i, залежно від соціально-політичних умов, дальше театральне життя семінаристів періодично то згасало, то спалахувало. Багато яскравих особистостей, випускників семінарії, причинилися до створення українського професійного театру в Галичині 1864 p.
Аналіз основних досліджень і публікацій. Діяльність Львівської греко-католицької духовної семінарії як навчальної інституції $є$ предметом дослідження багатьох наукових розвідок. Зокрема iii детальну історію від моменту заснування і до моменту ліквідації подано у монографії отця Миколи Пристая “Львівська греко-католицька духовна семінарія 1783-1945 рр.” [10]. Як одну із складових дослідницького компоненту в різних галузях науки (історії, педагогіки, літературознавства, театрознавства), навчально-виховну роботу Львівської семінарії в різний період часу та/чи діяльність її вихованців аналізували Іван Франко [13; 14; 15], Станіслав Пепловський [8], Кирило Студинський [12], Юрій Кміт [4; 5], Ростислав Пилипчук [9]. Та попри наявність низки публікацій різного рівня, досі недостатньою мірою окреслено місце Львівської духовної семінарії грекокатолицького обряду в українському культурному відродженні кінця XVIII першої половини XIX ст. та іiї впливу на кілька поколінь галицької молоді. Адже вже від моменту заснування теологічного навчального закладу Львова, його керівництво пропагувало національно-естетичні методи виховання, що дало змогу сформувати в молодому поколінні українців розуміння національної ідентичності, пізнати мистецькі надбання слов'янських народів, вивчати український фольклор, проявити творчі здібності засобами театральних постав, писати оригінальних драматичних текстів.

Мета наукової розвідки - крізь призму тогочасних суспільно-політичних умов дослідити навчально-виховний процес у стінах Львівської духовної семінарії греко-католицького обряду 1794-1848 pр., однією зі основних складових якого була сценічна діяльність семінаристів, виокремити основні етапи театрального життя, а також вказати на ключові постаті, які сформували свої ідейно-естетичні цінності під час навчання в семінарії та сприяли розвитку українського театру в Галичині.

Виклад основного матеріалу дослідження. Театральні вистави 1874 р вихованців духовної 


\section{ТЕАТРАЛЬНЕ ЖИТТЯ ЛЬВІВСЬКОЇ ГРЕКО-КАТОЛИЦЬКОЇ ДУХОВНОЇ СЕМІНАРІЇ КІНЦЯ ХИІІПЕРШӦ̈ ПОЛОВИНИ ХІХ СТ.}

семінарії греко-католицького обряду у Львові грали в польською мовою $[1,10-11]$. Галичина віддавна перебувала під авторитетом польськокатолицького суспільства, тому саме польська література мала головний вплив на розвиток української драматургії в Галичині XVII-XVIII ст. “До Польщі з Західної Свропи прийшов і середньовічний театр і всі види середньовічної драми - містерії, мораліте, фарси, - і драма шкільна, блискуче репрезентована виставами по колегіях єзуїтських" $[11,13]$. Окрім того, щоб піднести рівень католицької школи і приваблювати абітурієнтів інших віросповідань, керівництво навчальних закладів католицького обряду впроваджувало в побут учнів релігійно-драматичні декламації та співи у школі та інших місцях $[11,19]$.

Першим ректором Генеральної грекокатолицької семінарії у Львові став випускник Барбареум (Barbaram), Королівської грекокатолицької духовної семінарії у Відні, о. Антін Ангелович, згодом галицький митрополит, а віцеректором - о. Микола Скородинський, що одночасно був викладачем співів та обрядів, однак пізніше співу та обряду своїх товаришів навчали самі студенти, оскільки ця праця забирала у віцеректора багото часу. Зміст навчальних курсів студентів семінарії зосереджувався насамперед на поглибленні їхніх знань у царині богослов’я, а також набутті вмінь проведення обрядів та оволодінні церковним співом [16, 82-83]. “У церкві було два хори. Кожним хором керував диригент (doctor chori, cantor) із двома віце-дирегентами. $<\ldots>$ Хористами, котрі змінювалися по семеро щотижня, були звичайні семінаристи останнього (шостого) року навчання, їх називали праксистами або пасторалістами” [10, 121]. У праці “Драма українська" Володимира Резанова зазначено, що студенти не хотіли займатися церковною справою, а тільки писали комедії та грали в них $[11,13]$.

Спершу умови для навчання були далеким від належних: "Гостро відчувався брак спалень та кімнат для спільного навчання, а 31806 р. аудиторій, оскільки в частині приміщень була розміщена російська військова лікарня" $[16,82]$. Проте $з$ часом налагоджено умови проживання семінаристів та навчально-виховний процес. У будівлі семінарії було облаштовано актовий зал, що одночасно виступав як одна із викладових аудиторій, окрім того, в семінарському городі, що мав три площі, постійно проводились ігри і забави, особливо це було актуально влітку та під час осінніх канікул [10, 42].

У 1787 р. для тих студентів, які не володіли латиною, було організовано Studium Rutihenium, де запроваджено навчання народною мовою [16, 84-85].
С. Пепловський та I. Франко зазначили, що в 1794 р. семінаристи поставили комедії Францішека Богомольця польською мовою без жіночих персонажів, а згодом ще кілька інших авторів. Серед акторів-семінаристів дослідники відзначили Йосипа Чернецького, що “визначувався гарним талантом драматичним” [15, 320].

Наступним кроком розвитку театрального мистецтва у стінах Львівської семінарії став показ вистав 1797 р. Серед галицьких семінаристів того часу, що вели активну мистецьку діяльність, I. Франко виокремив літературну та театральну роботу Івана Сточкевича: “Син бідних родичів, він мусив вступити до семінарії, не можучи інакше утриматися в школах. Та література і театр займали його більше від догматики та катехитики". І. Франко зазначив, що саме під впливом професора В'ячеслава Гана, першого очільника українського філософського та богословського інституту "Studium Ruthenum” (“Руська Навчальна") у Львівському університеті, I. Сточкевич зайнявся літературною, зокрема перекладацькою діяльністю, переклав польською мовою ідилічно-сентиментальну поему "Весну” Евальда Кляйста та зробив чимало перекладів п’єс для семінарських вистав [10, 34]. Як приклад, у праці “Український театр в Галичині" С. Пепловський навів його переклад з німецької “Легковажність і добре серце”, який згадував й I. Франко під назвою “Syn marnotrawny” [15, 321]. Цю виставу показували “в останні дні запуст (перед початком посту)” [8, 34], а головну роль блудного сина грав сам автор одноактівки I. Сточкевич $[8,34]$.

Саме постаттю I. Сточкевича завершується перший період театрального життя Львівської духовної семінарії греко-католицького обряду, і лише в 1829 р. після 32 років мистецького затишшя, під час язичницького свята М'ясниці, останнього тижня перед Великим постом, коли ще можна святкувати весілля в семінарії відродилися театральні дійства, щоправда польською мовою [8, 34], що мали великий резонанс у Львові: “На ті вистави допущено гостей і з-поза мурів семінарії; в їх числі був і директор польського театру, заслужений двигач польської штуки, звісний нам уже 3 Камянця ЯнНеп.[омуцен] Камінський, котрий про ті вистави виражався з великою похвалою” [15, 321].

Це був не простий час, адже в той період у Галичині панувала епідемія холери: “Пошесть пропасниці та иньших недуг, які появилися в семинариї протягом 1830 i 1831 року, веліли шукати за ії причинами не тілько в самім лихім будинку та в переповненю по комнатах. I небаром 


\section{ТЕАТРАЛЬНЕ ЖИТТЯЛЬВІВСЬКОӤ ГРЕКО-КАТОЛИЦЬКОЇ ДУХОВНОЇ СЕМІНАРІЇ КІНЦЯ ХVІІІПЕРШӦ̈ ПОЛОВИНИ ХІХ СТ.}

виявилося, що при столі пило шістьох питомців воду з одної склянки, що з причини браку приладів до миття по кількох питомців нараз милося в одній мисці, а через те росла в семинариї нехарність” [12, VII-VIII]. У період з 1829 до 1842 р. померли 24 семінаристи.

У піковий період епідемії холери на західноукраїнських землях у Львівській грекокатолицькій духовній семінарії ректорували Гавриїл Дубовицький (1820-1829), Стефан Теліховський (1832-1836), Венедикт Левицький (1836-1837) [10, 180]. Особливо важкий період у житті семінарії (переповненість закладу, епідемія холери, заворушення серед студентів) припав на правління С. Теліховського.

Окрім того, в семінарії 1829-1837 pp. провадилась активно виховна робота із семінаристами та постійні ревізії. Заборонялися будь-які театральні дійства чи їх відвідування, носіння світської одежі, також до провин семінаристів відносили: “'занедбуванє церковних обов'язків, пізне вставанє, утеча (“шкарти”) 3 проходів, або викладів, куренє тютюну і гра в карти” [12, LXIII]. У зв'язку з чим діяла сувора система покарання: “упімненє (зауваження М. Ц.), прилюдна догана в музею (кімната для колективного навчання - М. Ц.), здержанє від одної, або більше страв при обіді, карцер <..>, видаленє з семинариї, а при тяжчих провинах виключенє з духовного стану" [12, LXIII]. Сувора система покарань функціонувала до 1842 р.

Попри те в семінарії у той час було чимало талановитих артистичних сил та продовжувало вирувати театральне життя. І. Франко записав зі свідчень о. Онуфрія Ганкевича, сучасника М. Шашкевича, що семінаристами зіграно дві вистави 1833 р. або 1834 р.: “Директор польського театру Камінський на ті представлення випозичив питомцям своїх декорацій і костюмів і сам був при них присутнім. Співи хорові і сольові дуже йому сподобались, і він почав був навіть вербувати співаків-семінаристів до свого театру, обіцюючи їм добру плату. Співом управляв Григорій Шашкевич, котрий і сам мав прекрасний тенор. В грі на сцені відзначувалися надто Ковальський, Ріпецький, Слоневський. Представлення відбувалися по-польськи. Грано якусь штуку про Петра Великого” [13, 452]. Актор, директор театру Товариства “Руська Бесіда" Т. Гембицький у праці "Исторія основаня і розвою руссконародного театру в Галичинс", окрім Василя Ковальського та Кирила Слоневського, згадав акторів-семінаристів Щудлинського та Урицького $[7, \mathrm{VII}]$.

Перша половина XIX ст. знаменується в
Галичині українським національним відродженням, очолене представниками свідомого грекокатолицького духовенства. На той час ректором Львівської семінарії призначено Григорія Яхимовича (1837-1848). У стінах семінарії формується осередок майбутніх подвижників українського культурного відродження утворюється товариство “Руська трійця", укладається перша рукописна поетична збірка українською мовою в Галичині “Син Русі”, друкується альманах "Русалка Дністрова”. Завдяки зусиллям талановитих семінаристів P. Моха, А. Могильницького, О. Шухевича та М. Вербицького “в семінаріи устроювано театральні вистави, концерти и ріжні забави” [7, VII]. I. Франко, окрім Р. Моха, відзначив також Кашубинського і Твардієвича: “Талант їх, стіснений строгою семінарською, майже монастирською дисципліною, проявлявся тільки случайно, в імпровізованих діалогах характеристичних, котрі попросту очаровували цілу семінарію і становили на цілі тижні зміст розговорів" [14, $357-$ 373]. Г. Яхимович, за припущеннями Д. Вінцковського, свої народницькі погляди, які сповідував усе життя, викристалізував під впливом діяльності А. Ангеловича [2, 13], який і скерував Г. Яхимовича на навчання до Відня, де до юнака прийшло розуміння своєї національної приналежності, а згодом, завдяки своїй праці, зумів посісти гідне місце серед церковних та громадсько-політичних діячів Галичини XIX ст. Усвідомлюючи усю значимість поступу українського слова, Г. Яхимович не тільки не забороняв читання семінаристами імпровізованих діалогів “"(напр.[иклад], між хлопом і жидом, між торговцем і хлопом на ярмарку)” [14, 357-373], але і спонукав вихованців до постановки театральних вистав. Саме за його ректорування в семінарії поставлено "Ruskoje wesile" (“Руське весілля") Й. Лозинського, яке видано автором у 1834 р., $з$ живими типами і образами народного весілля, його обрядами і піснями. Це була перша спроба вивести українську мову на сцену семінарії.

Львівська греко-католицька духовна семінарія в 1836-1848 рр. виховала цілу плеяду мислителів, які підняли і возвеличили Україну, їі культуру і мову: “І великою була сила їх слова, діла і приміру” [12, CCXLI]. Серед них культурно-освітні діячі (Іван Вітошинський, Іван Озаркевич); літератори (Йосафат Кобринський, Михайло Козанович, Антон Могильницький, Микола Устиянович, Келестин Скоморовський), драматурги (Родольф Мох, Іван Гушалевич); композитори (Микола Вербицький, Іван Лаврівський), що спричинилися 


\section{ТЕАТРАЛЬНЕ ЖИТТЯ ЛЬВІВСЬКОЇ ГРЕКО-КАТОЛИЦЬКОЇ ДУХОВНОЇ СЕМІНАРЇ̈ КІНЦЯ ХVІІПЕРШОӤ ПОЛОВИНИ ХІХ СТ.}

до розвитку українського професійного театру в Галичині.

І. Озаркевич у грудні 1848 р. в Коломиї поставив “Дівка на виданню або На милування нема силування" за п'єсою I. Котляревського “Наталка Полтавка”, а згодом й інші твори наддніпрянської драматургії. М. Устиянович здійснив перший переклад драми польського письменника Ю. Коженьовського "Каграссу górale" ("Карпатські верховинці"). Під назвою "Верховинці" п’єса на дві дії з музикою М. Вербицького ставилася у багатьох театрах України. Виставу “Козак і охотник”, переробка I. Вітошинського (Айталевича) п’єси німецького драматурга А. Коцебу “Kozak und Freiwilliges”, яку вперше виставив аматорський театр у Перемишлі 2 січня 1849 р., поставлено в травні 1864 р О. Бачинським у Руському народному театрі. К. Скоморівський (Долиняненко) у 1849 р. перекладав трагедію О. Хом'якова “Срмак” 3 російської мови [9], а І. Вагилевич п’єсу німецького драматурга Ф. Шіллера "Інтрига i любов".

Вагоме місце в розвитку української драматургії посідає творчість Р. Моха, який у 1837 р. вступив до Львівській греко-католицької духовної семінарії - спершу як екстерніст, а згодом, перевівшись 3 латинського обряду на український за підтримки земляка і на той час префекта о. Михайла Малиновського, як семінарист. Р. Мох походив із давнього українського роду, його дід Лаврентій Мох був заможним міщаниномгосподарем. Рано осиротівши, Р. Мох був взяти під опіку бережанського українського пароха, декана о. Михайла Павликова, який не лише дав йому грунтовну освіту та навчив читати і писати українською мовою, що “тоді було рідким явищем, бо в руських попівських домах панувала скрозь польщина” [7, V], а й “привернув єго до руського обряду и навчив єго любити той обряд и руську народність" [7, V].

У стінах Львівської греко-католицької духовної семінарії Р. Мох розпочав писав короткі діалоги та розігрувати їх разом із семінаристами. Активна участь у театральному житті семінарії підштовхнула Р. Моха до письменницької діяльності - у 1841 р. він видав першу збірку поезій “Мотиль”. У 1845 р., використовуючи сценічний досвід здобутий у семінарії, “найпопулярніший спадкоємець М. Шашкевича" заснував на парафії в селі Лагодові коло Глинян вокальну школу для селян та створив хор, що за свідченням українського бібліографа І. Левицького, мав чималу славу в усій околиці: "Не було празника в сусідних селах и в недалекім Уневі, де би о. Мох зо своїм хором не був любим и пожаданим гостем" [7, IX]. Окрім того, Р. Мох був неперевершеним оратором, багато подорожував та займався місіонерською роботою: “Майже не було села в теперішній станиславівскій и в полудневій части львівськои епархіи, де би Мох не виголосив проповіди, де би люде не сміялися и не плакали під впливом єго слова..." [7, ХІІ]. Окремим виданням вийшла у Львові промова Р. Моха “Слово до народу галицько-руського”, виголошена 12 жовтня 1848 p.

Як драматург Р. Мох уперше проявив себе в 1849 р. віршованою драмою “Терпен-спасен”, що лише в 1878 р. вийшла окремим виданням під заголовком “Пам'ятка 3. Мая 1848” [6]. Цю п’єсу вперше було поставлено аматорським театром 15 травня 1849 р. на фестинах, присвячених роковинам скасування панщини в Галичині: “Постановка відбулася увечері в поєзуїтськім огороді. Свято було многолюдне, прибув великий здвиг народу - делегації від багатьох громад 3 усієї Галичини. На великій арені не вмістилася навіть половина бажаючих подивитися виставу. Були присутні поважні державні мужі, серед них губернатор Голуховський” [6, 244]. У цьому ж році Р. Мох опублікував першу галицьку комедію “Справа в сель Клекотинђ”, про життя селян за часів панщини. Перебуваючи на парафії коло Станіславова Р. Мох продовжував у своїй драматургії розкривати народні образи. Т. Гембицький зазначив, що комедії “Справа в сель Клекотинъ”, "Проциха” (музика М. Вербицького) та “Опъкуньство” було поставлено на сцені театру в Станіславові, а згодом О. Бачинським у Львові $[3,6]$.

Проте постійне переслідування та численні арешти семінаристів-українців австрійською і польською урядовими системами, призвели до занепаду інтелектуального та культурного життя в Галичині. Останнім відголоском національного пробудження стала комедія В. Ковальського “П'яниця”, написана у 1848 р.: “Твір цей відрізнявся дуже жвавою дією та чистою мовою, однак на сцені “П'яниця" досі не з'явився” [8, 35].

Висновки та перспективи подальших досліджень. Львівська греко-католицька духовна семінарія від моменту іiі заснування (1873) і до демократичної революції в Австрійській імперії (1848) була одним із основних осередків виховання і творчого зростання національно-свідомої української молоді, епіцентром національного відродження, домівкою “Руської трійці”, а згодом альма-матір’ю української драматургії.

Розпочавши сценічну діяльність у 1874 р. 3 постав п’єс драматурга Ф. Богомольця 


\section{ТЕАТРАЛЬНЕ ЖИТТЯ ЛЬВІВСЬКОЇ ГРЕКО-КАТОЛИЦЬКОЇ ДУХОВНОЇ СЕМІНАРІЇ КІНЦЯ ХVІІПЕРШӦ̈ ПОЛОВИНИ ХІХ СТ.}

польською мовою, семінаристи, за керівництва А. Ангеловича, працювали над вивченням української мови, пісень й обрядів та продовжували вести активне театральне життя в семінарії до 1797 р., основним проявом якого були різноманітні сценки в період церковних свят. Після більше ніж тридцятилітнього затишшя у 1829 р. у Львівській греко-католицькій духовній семінарії відродилася сценічна діяльність, незважаючи на важкі побутові умови, епідемію холери, яка в той час панувала в Галичині, жорсткі дисциплінарні порядки, які провадило керівництво, зокрема ректор С. Теліховський, семінаристи продовжували підпільно читати імпровізовані діалоги, записувати та вивчати усну народну творчість, перекладати драматичні твори та писати власні п'єси. Перебуваючи у вирі європейських подій, повстання 1848 р., що отримало назву “весна народів”, питомці Львівської греко-католицької духовної семінарії ставлять першу україномовну виставу - "Руське весілля” Й. Лозинського, а I. Озаркевич у 1848 р. в Коломиї - “Дівку на виданню або На милування нема силування” за п'єсою I. Котляревського “Наталка Полтавка". На жаль, до створення першого українського професійного театру в Галичині залишалося ще важких шістнадцять років, проте завдяки національно-спрямованій виховній діяльності ректорів А. Ангеловича та Г. Яхимовича у стінах Львівської грекокатолицької духовної семінарії зросло кілька поколінь причетних до становлення у 1864 р. та розвитку українського театру в Галичині.

\section{ЛІТЕРАТУРА}

1. Schnür-Pepłowski S. Teatr Polski we Lwowie 1780-1881. Lwów: Skład główny w Księgarni Gubrynowicza i Schmidta, 1891 (Lwów: I. Związkowa drukarnia). $181 \mathrm{~s}$.

2. Вінцковський Д. Григорій Яхимовичъ и современное русское движеніе. Львовъ: Из типографіи Ставропигійского Института, 1892.95 с.

3. Исторія основаня і розвою русско-народного театру в Галичинъ составлена однымъ изъ найстаршихъ артистовъ русской сцены [Титом Гембицьким]. Коломыя: Черенками и изданіемъ М. Бђлоуса, 1904. 52 с.

4. Кміт Ю. 1848 рік і Львівська руська духовна семінария. Записки Наукового Товариства імені Шевченка: виходять у Львові що два місяиї під редакичєю Михайла Грушевського. Львів, 1901. Т. XL. Кн. II. С. 1-10.

5. Кміт Ю. Причинки до історії руського духовного семінаря у Львові від 1837-1851 p. Записки Наукового Товариства імені
Шевченка: наукова часопись, присьвячена передовсїм українській історії, фільольотї, етнографії виходить у Львові що два місяиі під редакиією Михайла Грушевського. Львів, 1909. T. XCI. Кн. V. C. 151-158.

6. Кукула Світлана. Віршована драма Рудольфа Моха "Терпен-спасен" - "Пам'ятка 3 мая 1848" Вісник Львівського університету: сер.: Філологічна. 2007. Вип. 39, ч. 2. С. 244-259.

7. Левицький І. Рудольф Мох. Справа въ сель Клекотинђ: драматичний сцены: зъ панщизняныхъ часовъ. Львов: Накладомъ А. Хойнацкого, 1900 (Львов: Зъ друкарнъ Ставроп. Института). 120 с.

8. Пепловський С. Український театр у Галичині. Переклад з польської Н. Бічуї. Просиеніум. Львів, 2014. Ч. 1-3. С. 33-41.

9. Пилипчук Р. Репертуар і сценічне мистецтво українського професіонального театру в Галичині (60-і роки XIX ст.). Просиеніум. Львів, 2007. Ч. 2-3. С. 3-14.

10. Пристай М. Львівська Греко-Католицька Духовна Семінарія 1783-1945: монографія; гол. ред. Богдан Прах. Львів, Рудно, 2003. 452 с.

11. Рєзанов В. Драма українська. Старовинний театр український. Київ: 3 друкарні Української академії наук, 1926. 202 с.

12. Студинський К. Львівська духовна семінарія в часах Маркіяна Шашкевича (18291843). Львів: Накладом Наукового товариства імени Шевченка, 1916 (Львів: 3 друкарнї Наукового товариства імені Шевченка). CCLX, $416 \mathrm{c}$.

13. Франко I. До історії нашого відродження. Франко І. Я. Зібрання творів у 50-и томах. Київ: Наукова думка, 1985. Т. 46, Ч. 1. С. 452-453.

14. Франко I. Руський театр в Галичині. Франко I.Я. Зібрання творів у 50-и томах. Київ: Наукова думка, 1980. T. 26. С. $357-373$.

15. Франко I. Русько-український театр (історичні обриси). Франко І.Я. Зібрання творів у 50-и томах. Київ: Наукова думка, 1981. Т. 29. C. $293-336$.

16. Хоркава I. Греко-католицька семінарія у Львові (1783-1929 рр.) як попередниця Грекокатолицької богословської академії. Наукові записки Національного університету "Острозька академія”. Серія “Релігієзнавство”. Острог, 2016. Випуск 1(13). С. 81-90.

\section{REFERENCES}

1. Schnür-Pepłowski, S. (1891). Teatr Polski we Lwowie 1780-1881 [Polish Theater in Lviv 1780 1881]. Lwów: Skład główny w Księgarni Gubrynowicza i Schmidta. (Lwów: I. Związkowa drukarnia). 181 p. [in Polish]. 
2. Vintskovskiy, D. (1892). Grigoriy Yakhimovich i sovremennoe russkoe dvizhenie [Hryhoriy Yakhymovych and the modern Ukrainian movement]. Lvov, 95 p. [Old Slavonic].

3. Istoriya osnovanya i rozvoyu russko-narodnogo teatru v Galichini sostavlena odnym iz naystarshikh artistov russkoy stseny Titom Gembitskim(1905). [The history of the creation and development of the Ukrainian National Theater in Galicia was written by one of the oldest actors of the Ukrainian stage Tit Gembitsky]. Kolomyya, 52 p. [Old Slavonic].

4. Kmit, Yu. 1848 rik i Lvivska ruska dukhovna seminaryia [1848 and Lviv Ukrainian Theological Seminary]. The notes of the Shevchenko Scientific Society: published in Lviv monthly under the editorship of Mykhaylo Hrushevskiy. Lviv, 1901. Vol. XL. Book. II, pp. 1-10. [in Ukrainian].

5. Kmit, Yu. (1909). Prychynky do istorii ruskoho dukhovnoho seminaria u Lvovi vid 1837-1851 r. [Facts on the history of the Ukrainian Theological Seminary in Lviv from 1837 to 1851]. The notes of the Shevchenko Scientific Society: A scientific journal devoted primarily to Ukrainian history, philology, and ethnography is published in Lviv monthly under the editorship of Mykhaylo Hrushevskiy. Lviv, Vol. XCI. Book. V, pp. 151-158. [in Ukrainian].

6. Kukula Svitlana (2007). Virshovana drama Rudolfa Mokha "Terpen-spasen" - "Pamiatka 3 maia 1848" [Poetic Drama Rodolfo Mocha "TerpenSaved" - "Memo on May 3, 1848"]. Bulletin of Lviv University: ser .: Philological. Vol. 39, part. 2, pp. 244-259. [in Ukrainian].

7. Levitskiy, I. Rudolf Mokh (1900). Справа въ сель Клекотинъ: драматичний сцены: зъ панщизняныхъ часовъ [An event in the village of Klekotyn: a dramatic scene during the serfdom]. Lvov, 120 p. [Old Slavonic].

8. Peplovskyi, S. (2014). Ukrainskyi teatr u Halychyni [Ukrainian theater in Galicia]. Translated from Polish by N. Bichui. Prostsenium. Lviv, part. 1-3, pp. 33-41. [in Ukrainian].

9. Pylypchuk, R. (2007). Repertuar i stsenichne mystetstvo ukrainskoho profesionalnoho teatru $\mathrm{v}$ Halychyni (60-i roky XIX st.) [Repertoire and stage art of the Ukrainian professional theater in Galicia (60s of the XIX century)]. Prostsenium. Lviv, part. 2-3, pp. 3-14. [in Ukrainian].

10. Prystai, M. (2003). Lvivska Hreko-Katolytska Dukhovna Seminariia 1783-1945 [Lviv Greek Catholic Theological Seminary 1783-1945]. (Ed.). Bohdan Prakh. Lviv, Rudno, 452 p. [in Ukrainian].

11. Riezanov,V. (1926). Drama ukrainska. Starovynnyi teatr ukrainskyi [Ukrainian drama. Ancient Ukrainian theater]. Kyiv, 202 p. [in Ukrainian].

12. Studynskyi, K. Lvivska dukhovna seminariia v chasakh Markiiana Shashkevycha (1829-1843) [Lviv Theological Seminary in the time of Markiyan Shashkevych (1829-1843)]. Lviv, 416 p. [in Ukrainian].

13. Franko, I. (1985). Do istorii nashoho vidrodzhennia [To the history of our revival]. Franko. A collection of works in 50. Kyiv, Vol. 46, part. 1, pp. 452-453. [in Ukrainian].

14. Franko, I. (1980). Ruskyi teatr v Halychyni [Ukrainian Theater in Galicia]. Franko. A collection of works in 50. Kyiv, Vol. 26, pp. 357 - 373. [in Ukrainian].

15. Franko, I. (1981). Rusko-ukrainskyi teatr (istorychni obrysy) [Russian-Ukrainian theater (historical aspect)]. Franko. A collection of works in 50. Kyiv, Vol. 29, pp. 293 - 336. [in Ukrainian].

16. Khorkava, I. (2016). Hreko-katolytska seminariia u Lvovi (1783-1929 rr.) yak poperednytsia Hreko-katolytskoi bohoslovskoi akademii [Greek Catholic Seminary in Lviv (1783-1929) as the predecessor of the Greek Catholic Theological Academy]. Scientific notes of the National University "Ostroh Academy”. Religious Studies Series. Ostroh, Vol. 1(13), pp. 81-90. [in Ukrainian].

Стаття надійшла до редакції 11.01.2021

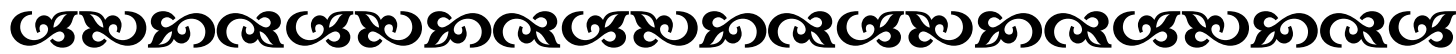

"Науку може всяқий вивчити - один з велиқою, інший з меншою працею. Але від мистецтва отримує қожен стільки, скільки він сам в змозі дати”.

Артур Шопенгауер німеиький боілософ

“Ми знаходимо в житті лише те, що самі вқладаємо в нъого”.

Ральб Волдо Емерсон американський есеїст, поет $і$ брілософ

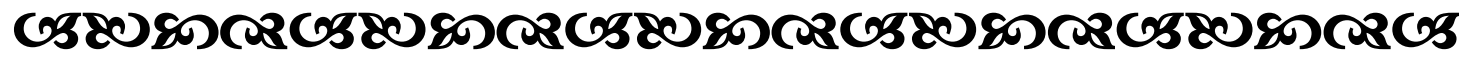

